\title{
Microbial Fuel Cell as a Bioelectrochemical Sensor of Nitrite Ions
}

\author{
Arnas Klevinskas ${ }^{1}$, Kristina Kantminienè ${ }^{1, * \mathbb{D}}$, Nerita Žmuidzinavičienè ${ }^{1}$, Ilona Jonuškiene் ${ }^{2} \mathbb{D}$ \\ and Egidijus Griškonis $1, * \mathbb{D}$
}

1 Department of Physical and Inorganic Chemistry, Faculty of Chemical Technology, Kaunas University of Technology, Radvilènu pl. 19, 50254 Kaunas, Lithuania; arnas.klevinskas@outlook.com (A.K.); nerita.zmuidzinaviciene@ktu.lt (N.Ž.)

2 Department of Organic Chemistry, Faculty of Chemical Technology, Kaunas University of Technology, Radvilènu pl. 19, 50254 Kaunas, Lithuania; ilona.jonuskiene@ktu.lt

* Correspondence: kristina.kantminiene@ktu.lt (K.K.); egidijus.griskonis@ktu.lt (E.G.)

Citation: Klevinskas, A.

Kantminienè, K.; Žmuidzinavičienè,

N.; Jonuškienė, I.; Griškonis, E.

Microbial Fuel Cell as a

Bioelectrochemical Sensor of Nitrite

Ions. Processes 2021, 9, 1330. https:// doi.org/10.3390/pr9081330

Academic Editor: Domenico Frattini

Received: 29 June 2021

Accepted: 28 July 2021

Published: 30 July 2021

Publisher's Note: MDPI stays neutral with regard to jurisdictional claims in published maps and institutional affiliations.

Copyright: (c) 2021 by the authors. Licensee MDPI, Basel, Switzerland. This article is an open access article distributed under the terms and conditions of the Creative Commons Attribution (CC BY) license (https:// creativecommons.org/licenses/by/ $4.0 /)$.

\begin{abstract}
The deteriorating environmental quality requires a rapid in situ real-time monitoring of toxic compounds in environment including water and wastewater. One of the most toxic nitrogencontaining ions is nitrite ion, therefore, it is particularly important to ensure that nitrite ions are completely absent in surface and ground waters as well as in wastewater or, at least, their concentration does not exceed permissible levels. However, no selective ion electrode, which would enable continuous measurement of nitrite ion concentration in wastewater by bioelectrochemical sensor, is available. Microbial fuel cell (MFC)-based biosensor offers a sustainable low-cost alternative to the monitoring by periodic sampling for laboratory testing. It has been determined, that at low $\left(0.01-0.1 \mathrm{mg} \cdot \mathrm{L}^{-1}\right)$ and moderate $\left(1.0-10 \mathrm{mg} \cdot \mathrm{L}^{-1}\right)$ concentration of nitrite ions in anolyte-model wastewater, the voltage drop in MFC linearly depends on the logarithm of nitrite ion concentration of proving the potential of the application of MFC-based biosensor for the quantitative monitoring of nitrite ion concentration in wastewater and other surface water. Higher concentrations $\left(100-1000 \mathrm{mg} \cdot \mathrm{L}^{-1}\right)$ of nitrite ions in anolyte-model wastewater could not be accurately quantified due to a significant drop in MFC voltage. In this case MFC can potentially serve as a bioelectrochemical early warning device for extremely high nitrite pollution.
\end{abstract}

Keywords: microbial fuel cell; biosensor; nitrite; Shewanella putrefaciens; graphite felt

\section{Introduction}

The growing human population and rapid development of industrial activities result in the increasing contamination of water [1]. Rapid recognition of toxic compounds and in situ real-time monitoring of their concentration are essential for water quality detection. Recently, microbial fuel cell (MFC)-based biosensors have drawn increasing interest due to their sustainability and cost-effectiveness [2].

In MFC, the energy stored in chemical bonds in organic compounds is converted to electrical energy through the catalytic reactions by microorganisms [3]. Electrons produced by the exoelectrogens from organic substrates by microbial metabolic pathways are transferred to the anode and flow to the cathode via an external circuit, containing a resistor or operated under a load, and are consumed at the cathode during the reduction of the oxidizing agent $[4,5]$.

MFC is a simple and robust technology, enabling direct conversion of organics energy into electrical energy, leading to simultaneous electricity generation and waste reclamation [6] and its application areas have been expanding exponentially [7]. For several decades, MFCs have been extensively studied and applied for the energy-harvesting [8,9], wastewater treatment $[1,10,11]$, recovery of valuable compounds [12-14], and as biosensors. MFC-based biosensor is one of the most promising technologies for toxicant determination 
in wastewater and other water bodies. A working principle of such an electrochemical biosensor is based on the change in microbial activity of bacteria-exoelectrogens as a very sharp response to toxicant. MFC-based biosensors are very cost effective and very sensitive devices [15]. Voltage can be easily monitored online, therefore, electric signal of MFC-based biosensor can be measured directly and no signal conversion is required on the contrary to the conventional sensors or measurement methods. The other advantages of MFC-based biosensors include working on-site, the possibility of portability, and miniaturization [6]. Furthermore, such biosensors do not require consumption of extra energy during sensing $[16,17]$. MFC-based biosensors have been studied to measure various parameters, including biochemical oxygen demand (BOD), chemical oxygen demand (COD), dissolved oxygen (DO), volatile fatty acids (VFAs), organic contaminants, antibiotics, heavy metals, toxicants, and microbial activity $[2,18-22]$

Highly reactive nitrite ion $\left(\mathrm{NO}_{2}^{-}\right)$is listed among toxicants naturally or artificially occurring in groundwater. Nitrite ions are part of nitrogen cycle in the environment along with ammonium $\left(\mathrm{NH}_{4}{ }^{+}\right)$and nitrate $\left(\mathrm{NO}_{3}{ }^{-}\right)$ions, nitrous oxide (dinitrogen oxide, $\mathrm{N}_{2} \mathrm{O}$ ), nitric oxide (mononitrogen monoxide, $\mathrm{NO}$ ) and nitrogen gas $\left(\mathrm{N}_{2}\right)$ [23]. The main sources of nitrites include fertilizers in run-off water, sewage, and mineral deposits. Nitrite salts are widely used in food production for curing of meat products for inhibiting the growth of bacteria.

The presence of high levels of nitrite, as well as nitrate, is toxic to humans and animals. Inhalation of small amounts of nitrite can cause acute poisoning, and long-term intake can cause cancer to humans [24]. Nitrite disrupts the oxygen-delivering ability of hemoglobin in the bloodstream. Due to the role of nitrite, as well as nitrate, as a precursor of genotoxic $N$-nitroso compounds in endogenous nitrosation, nitrite and nitrate in drinking water are suspected to cause cancer in the gastrointestinal and urinary tract and at other sites [25]. Nitrite drinking water standards are set to protect bottle-fed infants up to approx. 3-6 months of age from the acute condition methemoglobinemia [26].

Nitrite levels in drinking-water are usually below $0.1 \mathrm{mg} \cdot \mathrm{L}^{-1}$. The WHO has set the maximum limit of nitrite in drinking water as $3 \mathrm{mg} \cdot \mathrm{L}^{-1}$ [25]. U.S. Environmental Protection Agency has set the maximum contaminant level for nitrite at $1.0 \mathrm{mg} \cdot \mathrm{L}^{-1}$ (as nitrite- $N$ ) [27]. Limit values permissible in drinking water are $0.05 \mathrm{mg} \cdot \mathrm{L}^{-1}$ (as nitrite- $N$ ) in Japan and $0.5 \mathrm{mg} \cdot \mathrm{L}^{-1}$ (as nitrite) in the European Union [28]. Nitrification in distribution systems can increase nitrite levels, usually, by $0.2-1.5 \mathrm{mg} \cdot \mathrm{L}^{-1}$, but potentially by more than $3 \mathrm{mg} \cdot \mathrm{L}^{-1}$ [25].

In wastewater treatment, nitrite forms as an intermediate product of nitrification and denitrification [29]. For economic and efficient nitrogen removal from wastewater treatment plants via simultaneous nitrification and denitrification, the nitrification process should stop at the level of nitrite such that nitrite rather than nitrate becomes the substrate for denitrification.

Therefore, monitoring the presence and concentration of nitrite ions is paramount for health, ecological, and technological reasons. The routine monitoring of nitrite ion concentration in water is carried out by periodic sampling for laboratory testing by molecular absorption spectrometric method [30]. Over the past decade, development of electrochemical sensors for detection of nitrite has progressed with respect to carbon material, metal material, metal organic framework, conducting polymer, and enzyme as well as construction approaches and sensing performances [31-40].

However, to the best of our knowledge no MFC-based biosensor of nitrite ions has been developed and tested for the continuous real-time monitoring of nitrite ion concentration in water and/or wastewater. Based on the observations above, we herein report the investigation of a dual-chamber microbial fuel cell employing Shewanella putrefaciens as a bioelectrochemical biosensor for continuous monitoring of nitrite ion concentration in artificial wastewater. 


\section{Materials and Methods}

\subsection{General Conditions}

All chemicals were of analytical or biochemical grade and were purchased from SigmaAldrich, St. Louis, MO, USA; Eurochemicals, Vilnius, Lithuania; Carl Roth GmbH + Co. KG, Karlsruhe, Germany. All microbial experiments were performed under strictly sterile conditions.

\subsection{Cell Cultures and Media}

Shewanella putrefaciens wild-type NCTC 10,695 [41] (DSM No.: 1818, DSMZ-German Collection of Microorganisms and Cell Cultures $\mathrm{GmbH}$, Braunschweig, Germany) were used as exoelectrogens in the microbial fuel cells. Single colonies on LB/agar plates (SigmaAldrich, St. Louis, MO, USA) freshly streaked from a frozen glycerol stock culture of S. putrefaciens were transferred to $15 \mathrm{~mL}$ of LB broth and incubated aerobically at $30{ }^{\circ} \mathrm{C}$ for $24 \mathrm{~h}$. Then $S$. putrefaciens was proliferated while shaking at $100 \mathrm{rpm}$ (ES-20 Compact Shaker-Incubator, Grant Instruments, Shepreth, UK) at $30{ }^{\circ} \mathrm{C}$ for $48 \mathrm{~h}$. Afterwards $15 \mathrm{~mL}$ of culture were spun down at $3000 \mathrm{rpm}$ (Hettich Universal 320R, Andreas Hettich GmbH \& Co, Tuttlingen, Germany) for $10 \mathrm{~min}$. The pellet was resuspended in $15 \mathrm{~mL}$ of LB broth and $10 \mathrm{~mL}$ of it was transferred with sterile syringe into $390 \mathrm{~mL}$ of anolyte-model wastewater.

Anolyte-model wastewater was obtained by mixing solution A, containing electron donor for bacteria (acetate) and main mineral substances, and trace metals solution B in volume ratio 1000:1 [42,43]. Concentrations of components in Solution A are as follows: $3 \mathrm{~g} \cdot \mathrm{L}^{-1}$ $\mathrm{CH}_{3} \mathrm{COONa} \cdot 3 \mathrm{H}_{2} \mathrm{O}, 0.015 \mathrm{~g} \cdot \mathrm{L}^{-1} \mathrm{CaCl}_{2}, 1.5 \mathrm{~g} \cdot \mathrm{L}^{-1} \mathrm{KH}_{2} \mathrm{PO}_{4}, 3.0 \mathrm{~g} \cdot \mathrm{L}^{-1} \mathrm{Na}_{2} \mathrm{HPO}_{4}, 0.46 \mathrm{~g} \cdot \mathrm{L}^{-1}$ $\mathrm{MgSO}_{4} \cdot 7 \mathrm{H}_{2} \mathrm{O}, 3.82 \mathrm{~g} \cdot \mathrm{L}^{-1} \mathrm{NH}_{4} \mathrm{Cl}$. Concentrations of components in Solution $\mathrm{B}$ are as follows: $1.5 \mathrm{~g} \cdot \mathrm{L}^{-1} \mathrm{FeCl}_{3} \cdot 6 \mathrm{H}_{2} \mathrm{O}, 0.15 \mathrm{~g} \cdot \mathrm{L}^{-1} \mathrm{H}_{3} \mathrm{BO}_{3}, 0.03 \mathrm{~g} \cdot \mathrm{L}^{-1} \mathrm{CuSO}_{4} \cdot 5 \mathrm{H}_{2} \mathrm{O}, 0.18 \mathrm{~g} \cdot \mathrm{L}^{-1} \mathrm{KI}$, $0.12 \mathrm{~g} \cdot \mathrm{L}^{-1} \mathrm{MnCl}_{2} \cdot 4 \mathrm{H}_{2} \mathrm{O}, 0.06 \mathrm{~g} \cdot \mathrm{L}^{-1} \mathrm{Na}_{2} \mathrm{MoO}_{4} \cdot 2 \mathrm{H}_{2} \mathrm{O}, 0.12 \mathrm{~g} \cdot \mathrm{L}^{-1} \mathrm{ZnSO}_{4} \cdot 7 \mathrm{H}_{2} \mathrm{O}, 0.15 \mathrm{~g} \cdot \mathrm{L}^{-1}$ $\mathrm{CoCl}_{2} \cdot 6 \mathrm{H}_{2} \mathrm{O}, 10 \mathrm{~g} \cdot \mathrm{L}^{-1}$ disodium edetate dihydrate $\left(\mathrm{Na}_{2}-\mathrm{EDTA} \cdot 2 \mathrm{H}_{2} \mathrm{O}\right)$. Freshly prepared anolyte-model wastewater was sterilized at $90 \pm 1^{\circ} \mathrm{C}$ for $6 \mathrm{~h}$ and then cooled down to room temperature.

Catholyte was prepared as anolyte, except that sodium acetate was not added.

\subsection{Design and Operation of MFC}

Two-chamber MFC with the network of interdigitate channels and $\sim 32 \mathrm{~mL}$ volume of anode and cathode chambers, separated by a $10 \times 10 \mathrm{~cm}$ size proton-exchange membrane (PEM) Nafion ${ }^{\circledR}$ NRE-212 (Fuel Cell Store, College Station, TX, USA) was constructed and used to investigate operation performance of the MFC as nitrite ion biosensor. MFC was operated in batch mode. Polyacrylonitrile-based graphite felt (GF) AvCarb G200 (Fuel Cell Store, TX, USA) square sheets with the dimensions of $7 \times 7 \times 0.65 \mathrm{~cm}$ (length $\mathrm{x}$ width $x$ thickness) were used as MFC anode and cathode. Before filling the MFC with anolyte and catholyte both GF electrodes were hydrophilized (wetted) with aqueous 10\% (v/v) propan-2-ol solution and washed well with distilled water.

Anolyte, supplied from the anolyte reservoir, was circulated with peristaltic pump BS100-1AQ (Fluid Technology Co., Ltd., Baoding, China) at $12 \mathrm{~mL} \cdot \mathrm{min}^{-1}$ flow rate under anaerobic conditions provided by constant flow of nitrogen gas (purity $99.996 \%(v / v)$ ) at $100 \mathrm{~mL} \cdot \mathrm{min}^{-1}$ flow rate in the anode part of the system. Catholyte, supplied from separate catholyte reservoir, was circulated with peristaltic pump BS100-1AQ (Fluid Technology Co., Ltd., Baoding, China) at $30 \mathrm{~mL} \cdot \mathrm{min}^{-1}$ flow rate. Continuous aeration of catholyte was performed by membrane air pump Schego M2K3 (SCHEGO Schemel\&Goetz GmbH\&Co KG, Germany) at constant $\sim 200 \mathrm{~mL} \cdot \mathrm{min}^{-1}$ flow rate of the air. Concentration of DO in catholyte both at the inlet to MFC and outlet from MFC was monitored with luminescent/optical DO probe connected to the multimeter Hach HQ40D (Hach Company, Loveland, CO, USA).

The influence of nitrite ions on the performance of the MFC, i.e., voltage generated by MFC, was evaluated by suddenly feeding nitrite ion-contaminated anolyte-model wastewater instead of the nitrite-free anolyte-model wastewater. The concentration of nitrite ions in the contaminated anolyte-model wastewater was changed from $0.01 \mathrm{mg} \cdot \mathrm{L}^{-1}$ to $1000 \mathrm{mg} \cdot \mathrm{L}^{-1}$ $\mathrm{NO}_{2}{ }^{-}$ions. The contaminated anolyte-model wastewater of the certain nitrite ion concen- 
tration was prepared as follows: into a $200 \mathrm{~mL}$ volumetric flask, $2 \mathrm{~mL}$ of stock sodium nitrite $\mathrm{NaNO}_{2}$ solution, in which $\mathrm{NO}_{2}{ }^{-}$ion concentration was 100-fold higher than the target concentration of the final anolyte solution, were poured, and the deaerated anolyte-model wastewater was added until the etched ring graduation marking (Table 1)

Table 1. Data for preparation of nitrite ion-contaminated anolyte-model wastewater.

\begin{tabular}{|c|c|c|c|}
\hline $\begin{array}{c}\text { Concentration of } \mathrm{NO}_{2}^{-} \text {Ions } \\
\text { in Stock } \mathrm{NaNO}_{2} \text { Solution, } \\
\mathrm{mg} \cdot \mathrm{L}^{-1}\end{array}$ & $\begin{array}{c}\text { Volume of Stock } \mathrm{NaNO}_{2} \\
\text { Solution, } \mathrm{L}\end{array}$ & $\begin{array}{c}\text { Volume of Nitrite } \\
\text { Ion-Contaminated } \\
\text { Anolyte-Model Wastewater, L }\end{array}$ & $\begin{array}{c}\text { Concentration of } \mathrm{NO}_{2}^{-} \text {Ions } \\
\text { in Nitrite Ion-Contaminated } \\
\text { Anolyte-Model Wastewater, } \\
\mathrm{mg} \cdot \mathrm{L}^{-1}\end{array}$ \\
\hline 1 & & & 0.01 \\
\hline 10 & & & 0.1 \\
\hline 100 & 0.002 & 0.2 & 1.0 \\
\hline 1000 & & & 10.0 \\
\hline 10,000 & & & 100.0 \\
\hline 100,000 & & & 1000.0 \\
\hline
\end{tabular}

Concentration of nitrite ions in stock $\mathrm{NaNO}_{2}$ solutions and prepared nitrite ioncontaminated anolyte-model wastewater solutions both at the inlet to MFC and outlet from MFC was monitored by a standardized molecular absorption spectrometric method [30]. Before the molecular absorption spectrometric analysis, all samples of nitrite ion-contaminated anolyte-model wastewater solutions were filtered through a sterile syringe filter (surfactant-free cellulose acetate membrane, $28 \mathrm{~mm}$ diameter and $0.45 \mathrm{~mm}$ pore size (Corning ${ }^{\circledR}$, Kaiserslautern, Germany). Measurements of the absorption of visible light at $540 \mathrm{~nm}$ wavelength of the analyzed solutions were performed in glass cuvettes with light path length of $10 \mathrm{~mm}$ by spectrophotometer PerkinElmer ${ }^{\circledR}$ Lambda 25 (PerkinElmer Inc., Waltham, MA, USA).

\subsection{Electrochemical Measurements}

In order to determine the optimal electric circuit load (resistance), at which the current generated by MFC was the highest at the lowest voltage, the operation of MFC under different electric circuit loads was investigated by directly connecting the potentiostatgalvanostat SP-150 (BioLogic ${ }^{\circledR}$, Seyssinet-Pariset, France) to the MFC. First, MFC was operating in an open circuit mode until inoculation of $S$. putrefaciens was complete and stable open circuit voltage value was achieved. Afterward, the resistance of electric circuit was gradually decreased from $32 \mathrm{k} \Omega$ to $15 \Omega$ programmatically by controlling the current such that the ratio of MFC voltage/current kept constant.

The operation of MFC was investigated by connecting an optimal passive electric load to it, i.e., a voltage divider consisting of $920 \Omega$ and $80 \Omega$ resistors connected in series. The total electric load was $1000 \Omega$. The voltage variation over time was measured across the $80 \Omega$ resistor by using data logger USB TC-08 (Pico ${ }^{\circledR}$ Technology Ltd., St Neots, UK) connected to the personal computer for data collection. The actual values of voltage and current generated by each MFC were calculated by applying Ohm's law for a part of the circuit. All MFC operation tests and electrochemical measurements were performed at room temperature $\left(22 \pm 1^{\circ} \mathrm{C}\right)$.

\section{Results and Discussion}

\subsection{Inoculation and Electric Load Selection of MFC}

The scheme of a setup of equipment used to investigate a MFC as a biosensor of nitrite ions is presented in Figure 1. At the initial stage, potentiostat-galvanostat SP-150 was connected to the MFC for the measurement of open circuit voltage and determination of the optimal electrical circuit load (resistance). When the further measurements were conducted, the voltage divider with optimal $1000 \Omega$ resistor and data logger USB TC-08 were connected to the MFC instead of the potentiostat-galvanostat SP-150. 


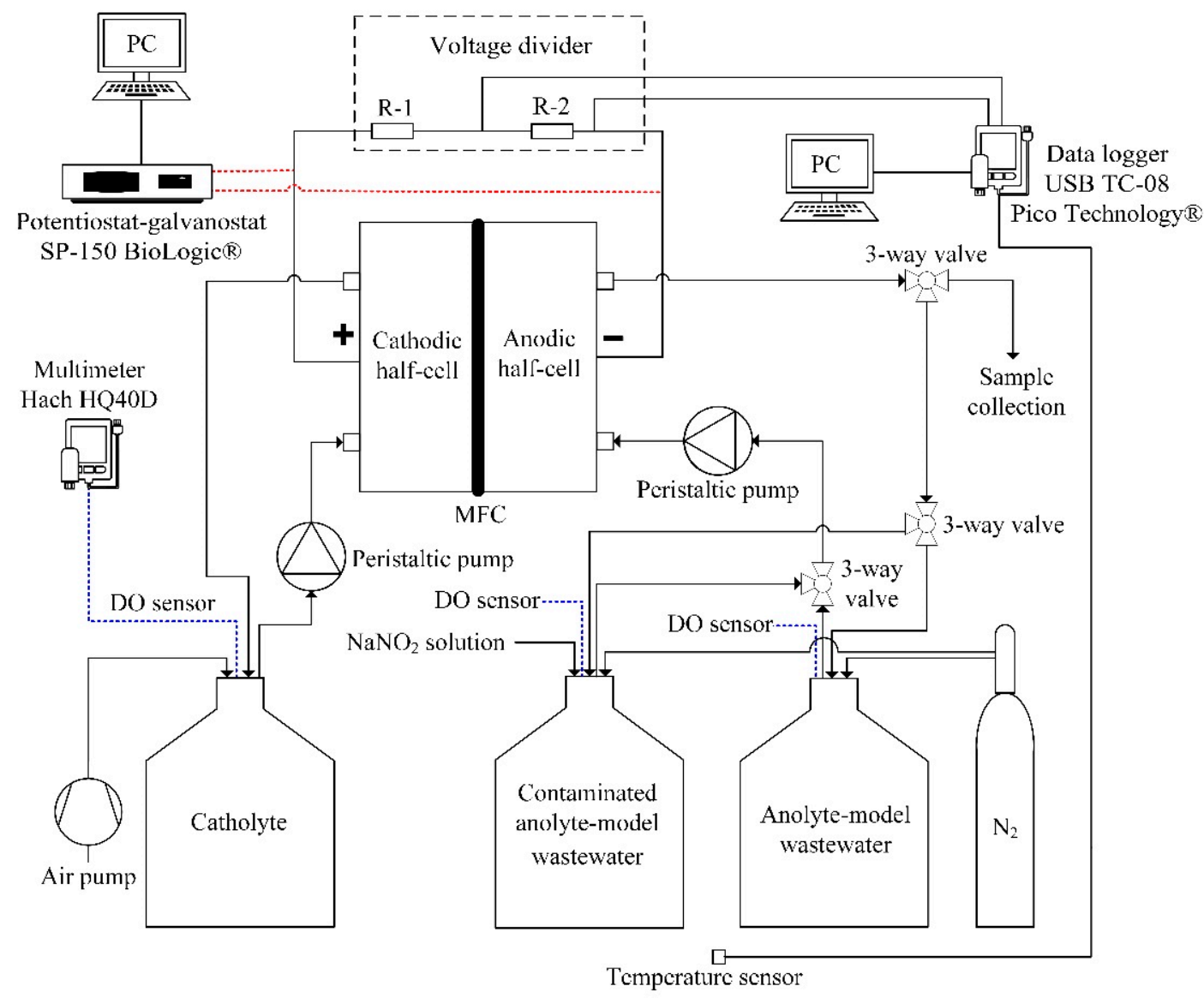

Figure 1. The setup of equipment used for investigation of a microbial fuel cell (MFC) as a nitrite ion biosensor. DOdissolved oxygen; PC-personal computer; R-resistor.

After filling the MFC system with appropriate electrolytes, particular care was taken to ensure that the catholyte circulating in the cathode half-cell of the MFC was sufficiently aerated and that there was no DO in the anolyte-model wastewater circulating in the anode half-cell. The change in DO concentration over time was monitored in both electrolytes with luminescent/optical DO probe connected to the multimeter Hach HQ40D (Hach Company, USA). During these measurements, the flow rates of catholyte and anolyte-model wastewater through the respective MFC half-cells was $30 \mathrm{~mL} \cdot \mathrm{min}^{-1}$ and $12 \mathrm{~mL} \cdot \mathrm{min}^{-1}$, respectively. Air was passing through the catholyte at a flow rate of $\sim 200 \mathrm{~mL} \cdot \mathrm{min}^{-1}$, and nitrogen gas was passing through the anolyte-model wastewater at a flow rate of $\sim 100 \mathrm{~mL} \cdot \mathrm{min}^{-1}$ to ensure anaerobic conditions. As it has been determined previously [44], higher catholyte circulation rate and more intensive aeration ensure that the MFC cathodic process is not limiting. The maximum concentration of DO $\left(7.2 \mathrm{mg} \cdot \mathrm{L}^{-1}\right)$ in the catholyte was achieved after approx. $15 \mathrm{~min}$ from the beginning of aeration. Meanwhile, complete deaeration of the anolyte-model wastewater to reach a concentration of $\mathrm{DO}<0.02 \mathrm{mg} \cdot \mathrm{L}^{-1}$ took approx. $35 \mathrm{~min}$ (Figure 2).

After assuring that the anolyte-model wastewater was completely deaerated, a suspension of S. putrefaciens bacteria (10 $\mathrm{mL}$ of suspension to $390 \mathrm{~mL}$ of anolyte) was added. From this point on, the change in MFC open circuit voltage over time was measured by the potentiostat (Figure 3). It was observed, that the MFC voltage increased steadily during the first $4 \mathrm{~h}$. Such a sudden rise in open circuit voltage can be attributed to bioanode formation, i.e., intense bacterial inoculation on the GF anode. When the MFC open circuit voltage reached a maximum value of $\sim 275 \mathrm{mV}$, it dropped insignificantly and stabilized at $\sim 250 \mathrm{mV}$ after $13-15 \mathrm{~h}$. 


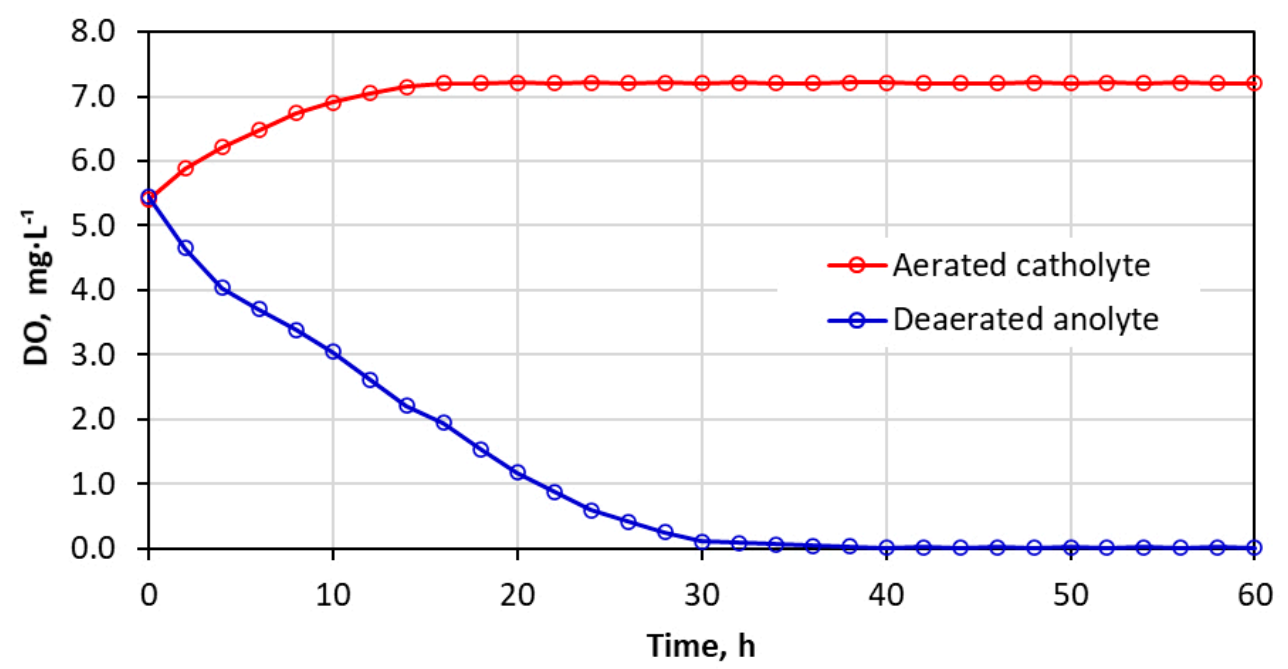

Figure 2. Change of dissolved oxygen (DO) concentration over time in aerated by air catholyte and deaerated by nitrogen gas anolyte-model wastewater.

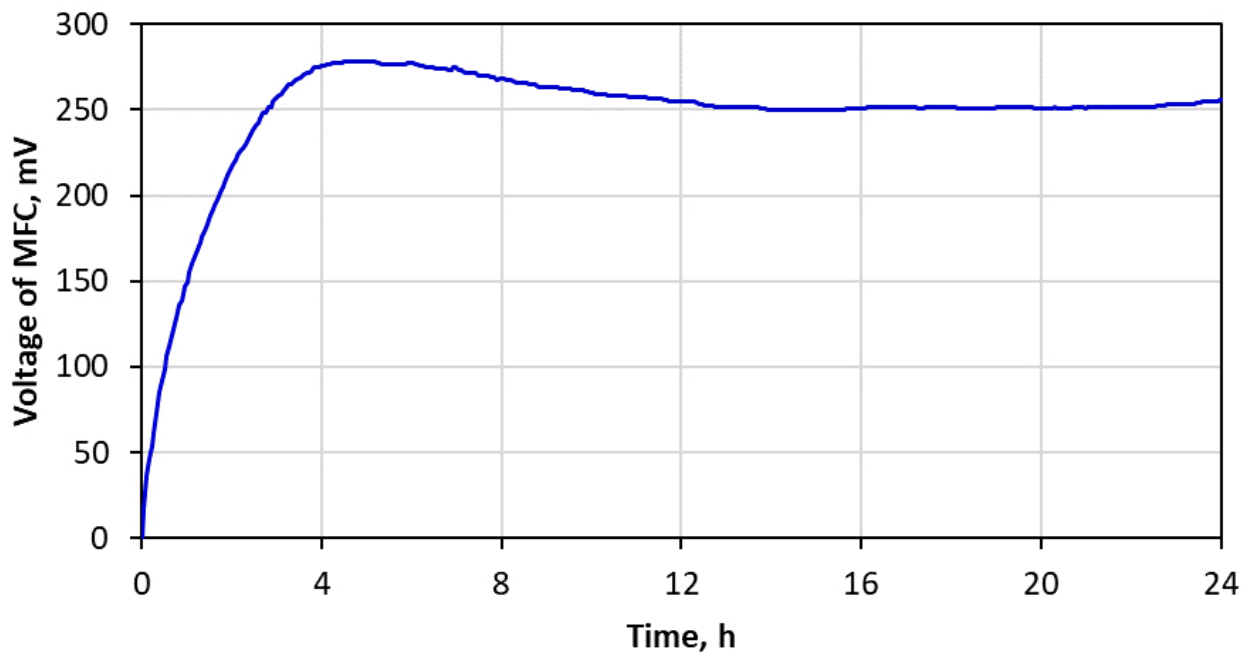

Figure 3. Variation of open circuit voltage of microbial fuel cell (MFC) over time at ambient temperature.

After stable MFC open circuit voltage was reached, MFC was periodically loaded with different electrical circuit resistance. The MFC was first loaded with a maximum resistance of $32 \mathrm{k} \Omega$, which was gradually reduced to $15 \Omega$. The duration of loading with different resistances was $15 \mathrm{~min}$, followed by an open circuit period of $45 \mathrm{~min}$. It had been observed that as the resistance of the external circuit connected to the MFC decreased, its voltage dropped steadily to almost $0 \mathrm{~V}$ (Figure $4 \mathrm{a}$ ). This is typical for any electrochemical current source when the circuit resistance approaches $0 \Omega$ (approaching a short circuit). Meanwhile, the current generated by the MFC increased steadily as the electrical circuit load decreased (Figure $4 \mathrm{~b}$ ) until it reached a maximum average current of $\sim 33 \mu \mathrm{A}$ at an external circuit resistance of $1 \mathrm{k} \Omega$. By further reducing the resistance of the external circuit, the average current generated by the MFC decreased steadily, although slightly. In addition, current fluctuations were observed at resistance below $125 \Omega$, which were particularly significant at the lowest circuit resistance $(15 \Omega)$. Thus, for the further investigation of the MFC as a nitrite ion sensor, the passive resistance of $1 \mathrm{k} \Omega$, at which MFC generated the highest average current at a voltage of approx. $25-30 \mathrm{mV}$, was chosen. 


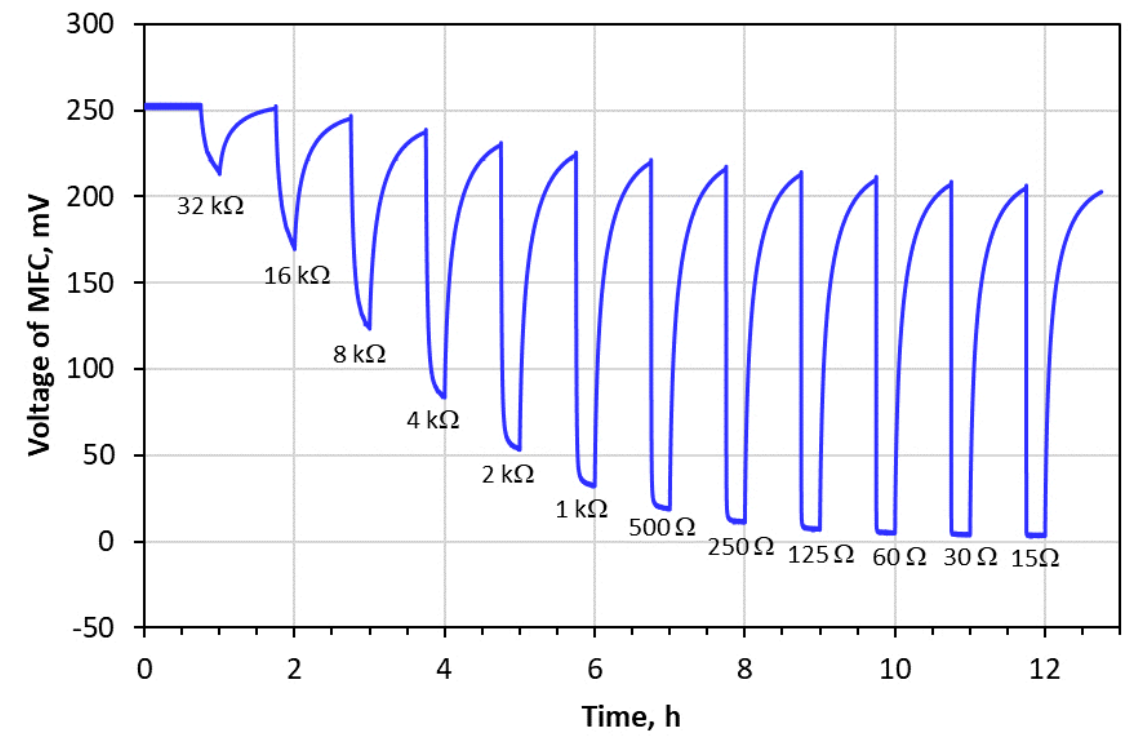

(a)

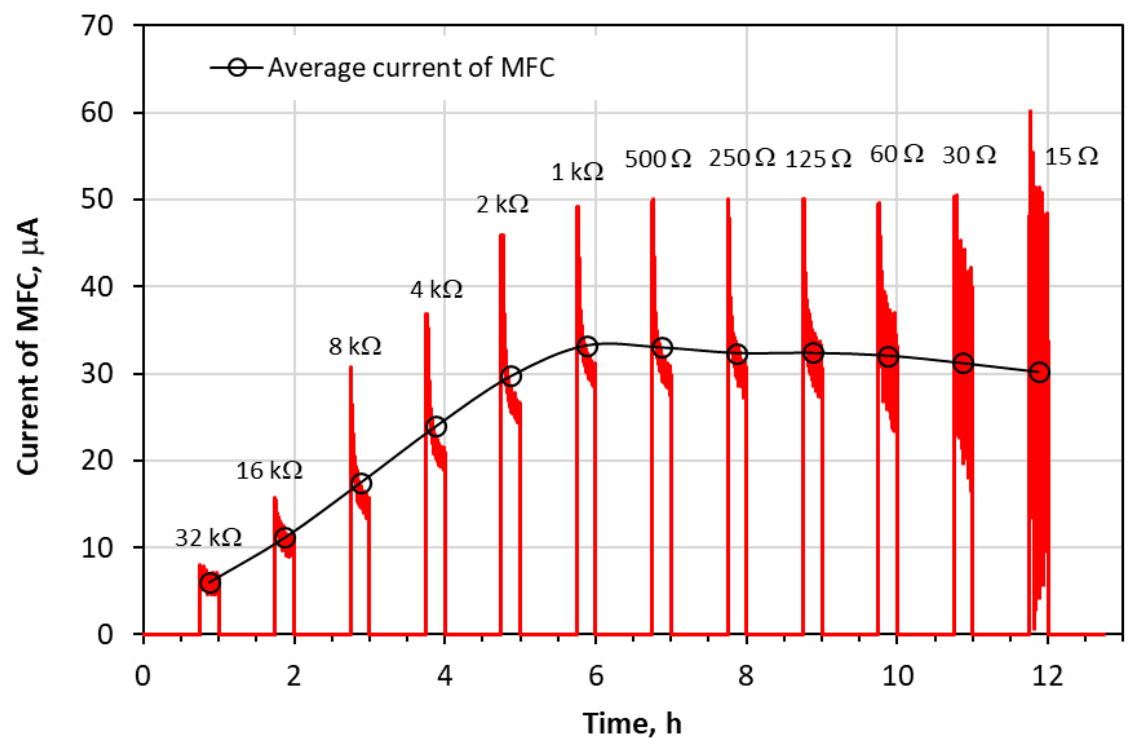

(b)

Figure 4. Dependence of voltage (a) and current (b) of microbial fuel cell (MFC) on different applied electric load.

\subsection{Influence of $\mathrm{NO}_{2}{ }^{-}$Concentration on MFC Voltage}

Total of $200 \mathrm{~mL}$ of contaminated anolyte-model wastewater solution of the certain nitrite ion concentration was prepared by taking a portion of the nitrite-free anolyte-model wastewater from an anolyte reservoir of the stabilized MFC and adding an appropriate volume of concentrated stock $\mathrm{NaNO}_{2}$ solution into it (Table 1). This solution of nitrite ion-contaminated anolyte-model wastewater was poured into a separate reservoir and deaerated with nitrogen gas at a flow rate of $\sim 100 \mathrm{~mL} \cdot \mathrm{min}^{-1}$ analogously as nitrite-free anolyte-model wastewater. A sudden drop in MFC voltage was observed after the abrupt replacement of the supply of nitrite-free anolyte-model wastewater to the anode half-cell of the MFC by the feed of contaminated anolyte-model wastewater at the same flow rate $\left(12 \mathrm{~mL} \cdot \mathrm{min}^{-1}\right)$ (Figure 5). After passing $80 \mathrm{~mL}$ of nitrite ion-contaminated anolyte-model wastewater through the anode half-cell of the MFC, the supply of nitrite-free anolyte-model wastewater to the MFC was restored. The rise of the MFC voltage was observed at once with the subsequent recovery to the baseline. Duration of such a recovery of the generated 
voltage level was 30-60 $\mathrm{min}$, when concentration of nitrite ions in the contaminated anolyte-model wastewater was low $\left(0.01-0.1 \mathrm{mg} \cdot \mathrm{L}^{-1}\right)$ and moderate $\left(1.0-10 \mathrm{mg} \cdot \mathrm{L}^{-1}\right)$. It is important to note, that the moderate concentration range covers the permissible levels of nitrite set by governing bodies worldwide $[25,27,28]$, thus proving the applicability of such a MFC-based biosensor for accurate quantification (Figure 6) of nitrite ions at the edge of the allowed contamination level. However, when the concentration of nitrite ions in the contaminated anolyte was from $100 \mathrm{mg} \cdot \mathrm{L}^{-1}$ to $1000 \mathrm{mg} \cdot \mathrm{L}^{-1}$, the MFC voltage did not reach the initial level even after more than $2 \mathrm{~h}$ of supplying nitrite-free anolyte to the MFC. It has been assumed that such a failure in recovery is due to the strong toxic effect of nitrite ions resulting in partial loss of the inoculated bacteria at the bioanode.

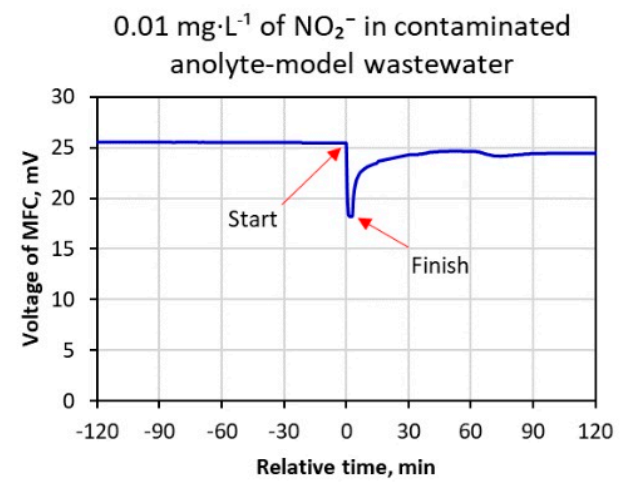

(a)

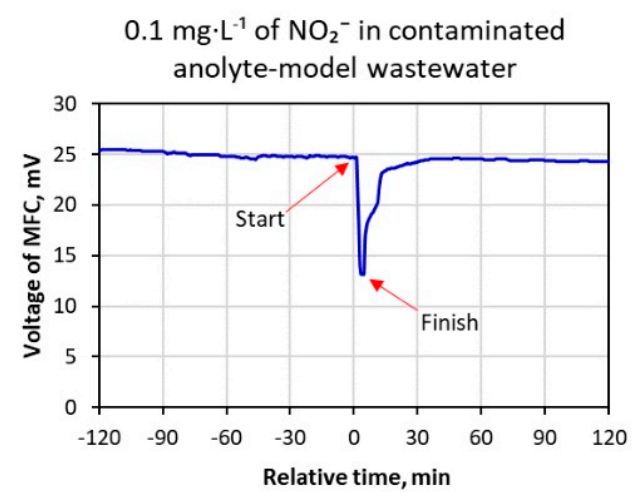

(b)

$1.0 \mathrm{mg} \cdot \mathrm{L}^{-1}$ of $\mathrm{NO}_{2}^{-}$in contaminated anolyte-model wastewater

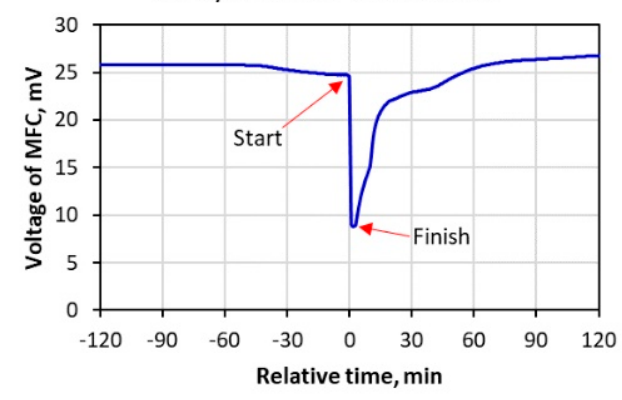

(c)

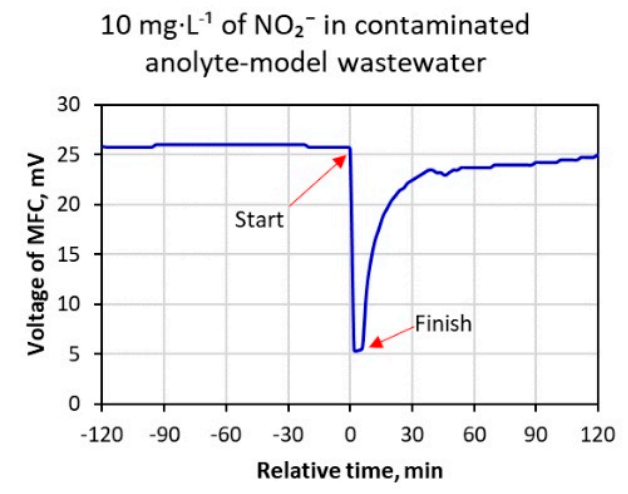

(d)

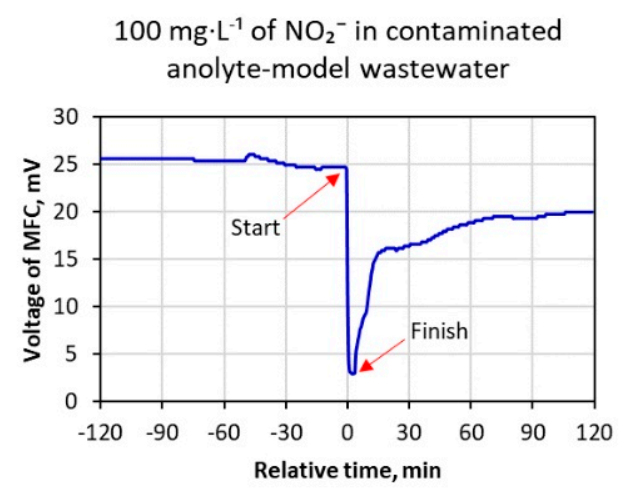

(e)

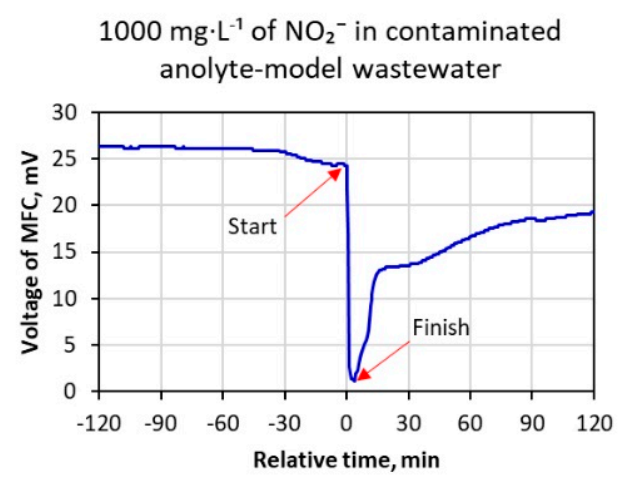

(f)

Figure 5. Variation of microbial fuel cell (MFC) voltage over relative time, when MFC was fed with nitrite-free anolyte-model wastewater (parts of the curves before Start point and after Finish point) and contaminated anolyte-model wastewater of different ((a) $0.01 \mathrm{mg} \cdot \mathrm{L}^{-1}$; (b) $0.1 \mathrm{mg} \cdot \mathrm{L}^{-1}$; (c) $1.0 \mathrm{mg} \cdot \mathrm{L}^{-1}$; (d) $10 \mathrm{mg} \cdot \mathrm{L}^{-1}$; (e) $100 \mathrm{mg} \cdot \mathrm{L}^{-1}$; (f) $1000 \mathrm{mg} \cdot \mathrm{L}^{-1}$ ) nitrite ion concentration (part of the curves between Start and Finish points). "Zero" time moment indicates the start of the supply of the nitrite ion-contaminated anolyte into MFC. 


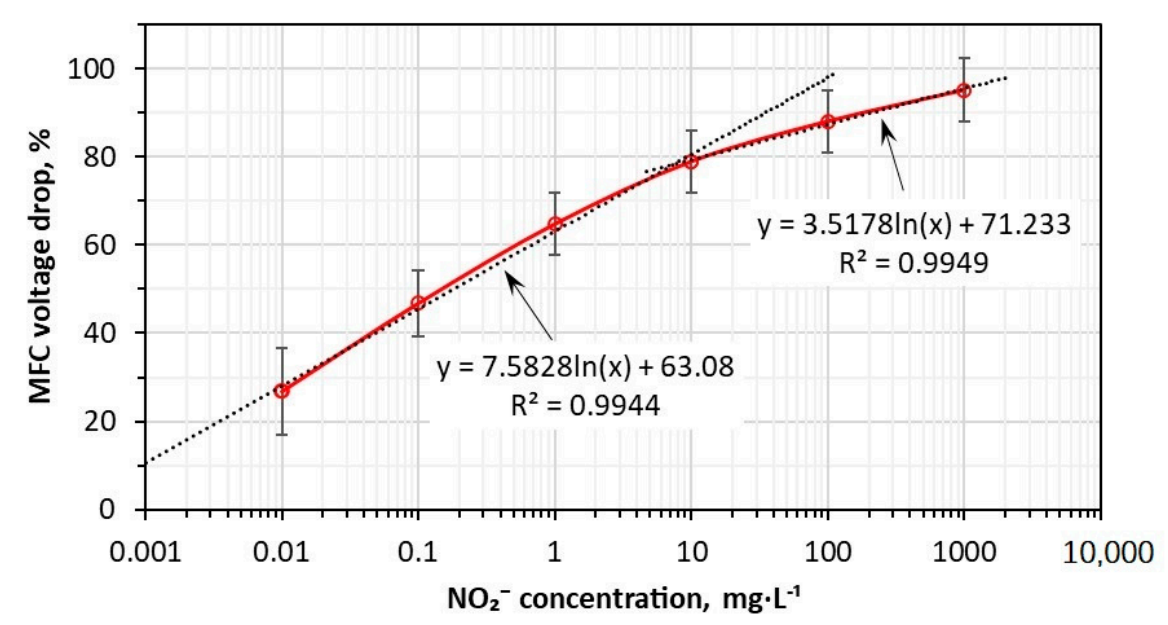

Figure 6. Dependence of microbial fuel cell (MFC) voltage drop on the concentration of nitrite ions in contaminated anolyte-model wastewater.

As seen from the results presented in Figure 6, in the concentration range from $0.01 \mathrm{mg} \cdot \mathrm{L}^{-1}$ to $10 \mathrm{mg} \cdot \mathrm{L}^{-1}$ of nitrite ions in nitrite ion-contaminated anolyte-model wastewater, there is a clearly expressed linear dependence of MFC voltage drop on logarithm of nitrite ion concentration in a contaminated anolyte-model wastewater. The lowest detectable nitrite ion concentration can be defined by a limit of detection (LOD). LOD is calculated as the ratio of the standard error of the regression $(\sigma)$ over the slope of the linear regression curve $(m)[45]$ :

$$
\mathrm{LOD}=3.3 \frac{\sigma}{\mathrm{m}}
$$

The calculated LOD for nitrite ion concentration is $\sim 0.0028 \mathrm{mg} \cdot \mathrm{L}^{-1}$.

The linear dependence of MFC voltage drop on logarithm of nitrite ion concentration is also observed in the range of concentrations from $10 \mathrm{mg} \cdot \mathrm{L}^{-1}$ to $1000 \mathrm{mg} \cdot \mathrm{L}^{-1}$. In this case, the MFC voltage drop values are very high (reaching $89 \%$ and $95 \%$, respectively) and differ among themselves insignificantly, therefore, the slope of the curve is lower what determines the lower measurement accuracy. In practice, the concentration of nitrite ions in wastewater very rarely exceeds $1000 \mathrm{mg} \cdot \mathrm{L}^{-1}$ [46]. Therefore, $1000 \mathrm{mg} \cdot \mathrm{L}^{-1}$ was used as the highest concentration in the present study. It should be noted that the upper limit of the linear range is restricted by the capacity of the electrochemically active biofilm [47], thus, the anode area should be increased to provide a larger area for biofilm formation. It could be expected that the application of a MFC for the more accurate measurement of the higher concentration of nitrite ions could be achieved by reducing the flow rate of the anolyte through the anodic half-cell, which is essentially in line with the extension of the analyzed anolyte-wastewater hydraulic retention time or by using multi-stage MFCs connected in series [20].

Therefore, the obtained results prove the possibility to use MFC as a nitrite ion biosensor for the accurate quantitative determination of nitrite ions in wastewater at lower concentrations or as an early warning system in the event of particularly high nitrite ion wastewater pollution.

\subsection{Change of Nitrite Ion Concentration in the Anolyte at the MFC Outlet}

While investigating the effect of different concentrations of nitrite ions in contaminated anolyte-model wastewater that was fed to the MFC on its voltage response, samples of the anolyte at the outlet from the MFC anode half-cell $(40 \mathrm{~mL}$ each) were collected simultaneously to determine the nitrite ion concentration in them. The diagrams of the distribution of nitrite ion concentration in individual samples of anolyte entering and leaving the MFC (Figure 7) show that when contaminated anolyte-wastewater with low concentration of nitrite ions $\left(0.01-0.1 \mathrm{mg} \cdot \mathrm{L}^{-1}\right)$ was supplied to the MFC, nitrite ions were completely leached from the MFC with the fourth sample after the nitrite-free anolyte-model wastewater 
feed to the MFC was restored. While anolyte-model wastewater containing medium and high concentration of nitrite ions $\left(1.0-1000 \mathrm{mg} \cdot \mathrm{L}^{-1}\right)$ was fed to the MFC, nitrite ions were completely leached from the MFC only with the fifth sample. In all cases, the sixth sample was free of nitrite ions. This retention of nitrite ions in the anode half-cell most likely determines the nature of the voltage-time dependence curves when the voltage drop is very sudden at the start of the supply of the nitrite-contaminated anolyte-model wastewater, whereas the recovery of the voltage level is much slower after the supply of the nitrite-free anolyte to the anode half-cell is resumed.

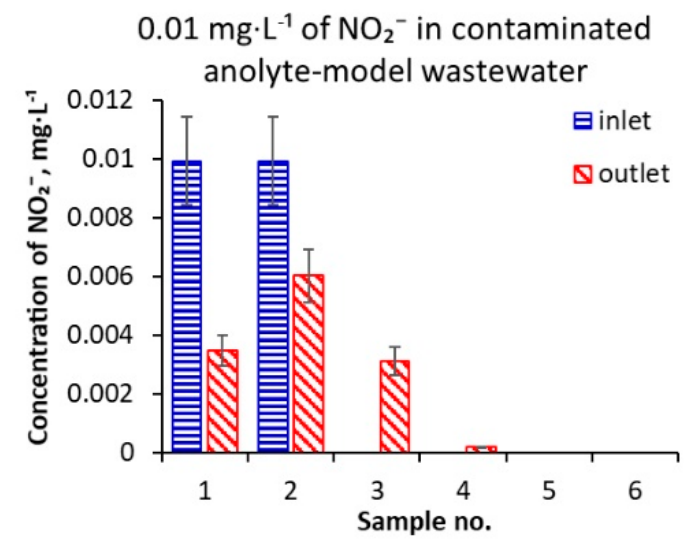

(a)

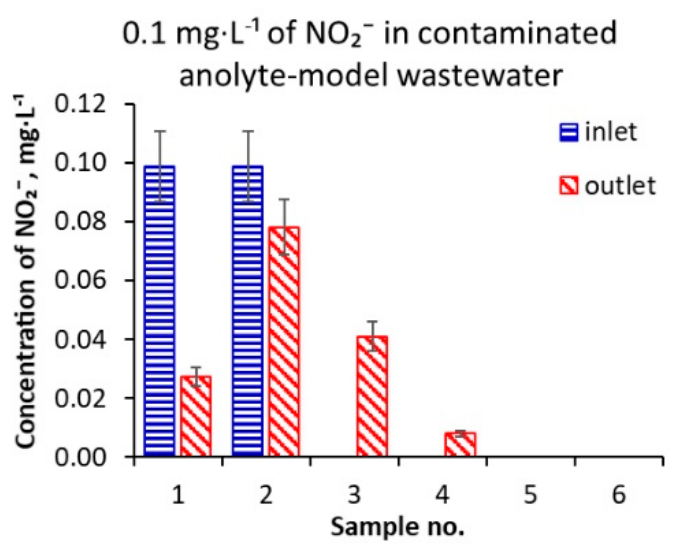

(b)

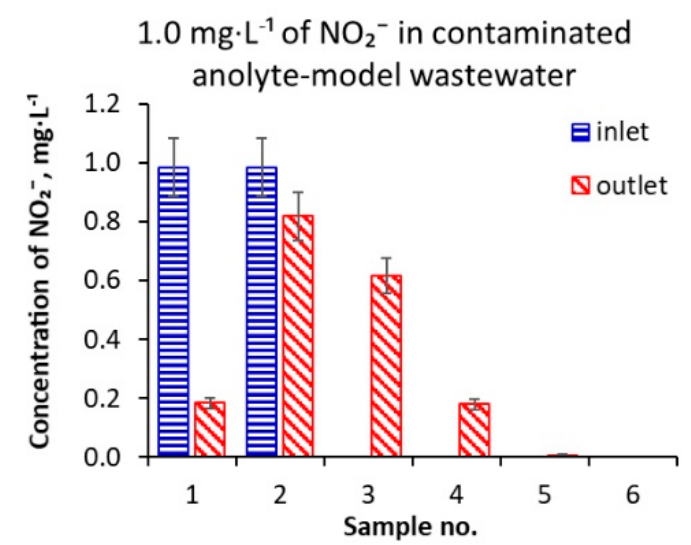

(c)

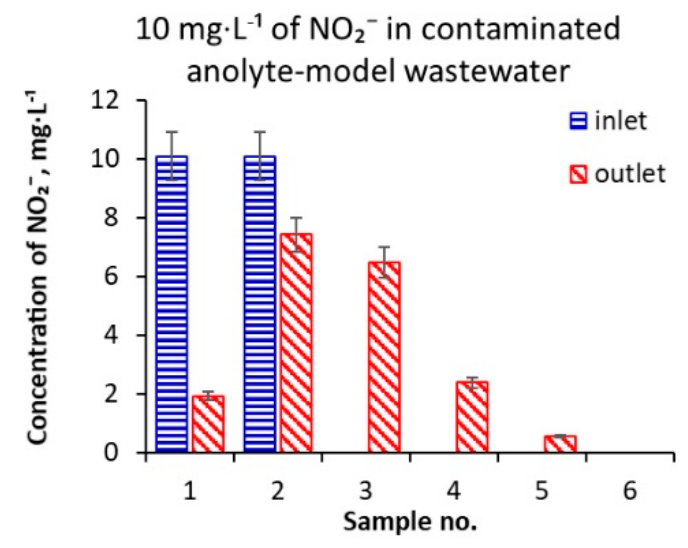

(d)

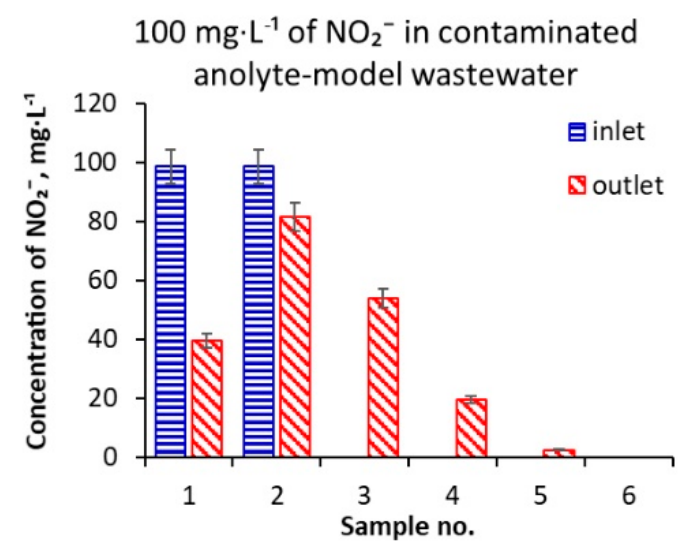

(e)

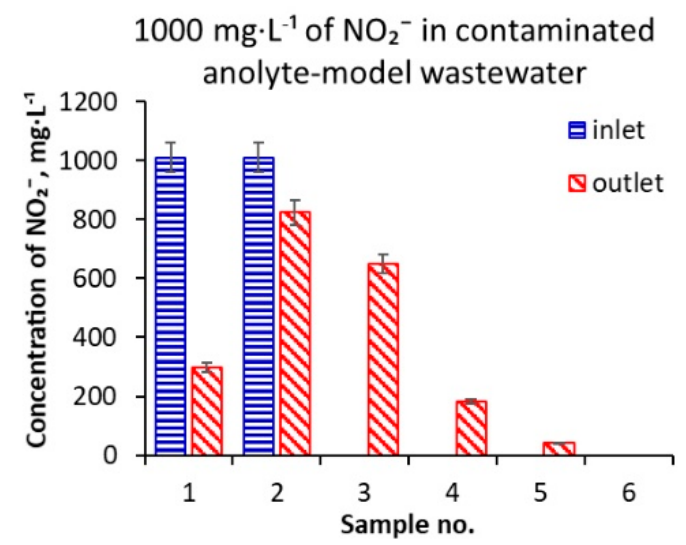

(f)

Figure 7. Change of nitrite ion concentration in the nitrite ion-contaminated anolyte-model wastewater at outlet of the microbial fuel cell (MFC) anode half-cell, when nitrite ion concentration at inlet was (a) $0.01 \mathrm{mg} \cdot \mathrm{L}^{-1} ;(\mathbf{b}) 0.1 \mathrm{mg} \cdot \mathrm{L}^{-1}$; (c) $1.0 \mathrm{mg} \cdot \mathrm{L}^{-1}$; (d) $10 \mathrm{mg} \cdot \mathrm{L}^{-1}$; (e) $100 \mathrm{mg} \cdot \mathrm{L}^{-1}$; (f) $1000 \mathrm{mg} \cdot \mathrm{L}^{-1}$. 
After the nitrite ion concentration in all collected samples was determined, the total nitrite content in the MFC anolyte effluent (totally 6 samples; $40 \mathrm{~mL}$ volume each) was calculated and compared with the total nitrite ion content in nitrite ion-contaminated anolyte-model wastewater that was fed into the MFC (2 samples; $40 \mathrm{~mL}$ volume each) (Table 2). In all cases, the total nitrite concentration in the anolyte-model wastewater samples collected at the outlet of the MFC anode half-cell was lower than that in the nitrite ion-contaminated anolyte-model wastewater samples collected at the inlet. A particularly significant decrease in nitrite ion concentration was observed in the case of anolyte-model wastewater containing low nitrite ion concentration $\left(0.01-0.1 \mathrm{mg} \cdot \mathrm{L}^{-1}\right)$. It was approx. $25-30 \%$, whereas the decrease in nitrite ion concentration in the samples of moderate concentration of nitrite ions $\left(1.0-10 \mathrm{mg} \cdot \mathrm{L}^{-1}\right)$ was approx. $5-10 \%$.

Table 2. Concentration and total mass of $\mathrm{NO}_{2}{ }^{-}$ions in nitrite ion-contaminated anolyte-model wastewater at the inlet and outlet of the microbial fuel cell (MFC) anode half-cell.

\begin{tabular}{|c|c|c|c|}
\hline $\begin{array}{c}\text { Concentration of } \mathrm{NO}_{2}^{-} \text {Ions } \\
\text { in Contaminated } \\
\text { Anolyte-Model Wastewater } \\
\text { Flowing into } \mathrm{MFC}, \mathrm{mg} \cdot \mathrm{L}^{-1}\end{array}$ & $\begin{array}{l}\text { Total Mass of } \mathrm{NO}_{2}^{-} \text {Ions in } \\
\text { Anolyte-Model Wastewater } \\
\text { Flowing into } \mathrm{MFC}^{*}, \mathrm{mg}\end{array}$ & $\begin{array}{l}\text { Total Mass of } \mathrm{NO}_{2}^{-} \text {Ions in } \\
\text { Anolyte-Model Wastewater } \\
\text { Flowing out of } \mathrm{MFC}^{* *}, \mathrm{mg}\end{array}$ & $\begin{array}{l}\text { Decrease in Nitrite Ion } \\
\text { Concentration in } \\
\text { Anolyte-Model Wastewater } \\
\text { Flowing out of MFC, \% }\end{array}$ \\
\hline 0.01 & 0.0008 & 0.00051 & 36.1 \\
\hline 0.1 & 0.008 & 0.00618 & 22.8 \\
\hline 1.0 & 0.08 & 0.0722 & 9.74 \\
\hline 10.0 & 0.8 & 0.749 & 6.31 \\
\hline 100.0 & 8.0 & 7.881 & 1.49 \\
\hline 1000.0 & 80.0 & 79.80 & 0.24 \\
\hline
\end{tabular}

* In two samples with volume of $40 \mathrm{~mL}$ each (total volume of samples $80 \mathrm{~mL}$ ); ${ }^{* *}$ in six samples with volume of $40 \mathrm{~mL}$ each (total volume of samples $240 \mathrm{~mL}$ ).

This decrease in nitrite ion concentration can be attributed to the partial reduction of these ions to $\mathrm{N}_{2}$ gas (denitrification) at the MFC bioanode [46,48]. The overall electrochemical processes, which take place on the surface of the anode and cathode during MFC operation, can be described by the following reaction equations [3]:

Anodic process: $\mathrm{CH}_{3} \mathrm{COO}^{-}(\mathrm{aq})+2 \mathrm{H}_{2} \mathrm{O}(\mathrm{l}) \rightarrow 2 \mathrm{CO}_{2}(\mathrm{~g})+7 \mathrm{H}^{+}(\mathrm{aq})+8 \mathrm{e}^{-}$

acetate

$$
\text { Cathodic process: } \mathrm{O}_{2}(\mathrm{~g})+4 \mathrm{H}^{+}(\mathrm{aq})+4 \mathrm{e}^{-} \rightarrow 2 \mathrm{H}_{2} \mathrm{O}(\mathrm{l})
$$

Since bacteria-exoelectrogens oxidize acetate ions at the bioanode and transfer electrons to the anode, nitrite ions entering the MFC anode half-cell compete for the electrons transferred by bacteria-exoelectrogens with the MFC anode. The reduction of nitrite ions at the bioanode when they gain electrons donated by bacteria-exoelectrogens can be described by the following electrochemical denitrification reaction equation [48]:

$$
\mathrm{NO}_{2}^{-}(\mathrm{aq})+2 \mathrm{H}_{2} \mathrm{O}(\mathrm{l})+3 \mathrm{e}^{-} \rightarrow \mathrm{N}_{2}(\mathrm{~g})+4 \mathrm{OH}^{-}(\mathrm{aq})
$$

It is very likely that "deficit" of electrons due to their transfer to nitrite ions by bacteriaexoelectrogens determines the increase of anode electrochemical potential and, therefore, the MFC voltage drop.

\subsection{Statistical Analysis}

All experiments were repeated at least three times, calculating the mean and standard deviation. The data were processed using Microsoft Office Excel 2016 software (Microsoft Corporation, Redmond, WA, USA). Statistical analysis was performed by using Student's $t$-test. The level of significance was set as $p<0.05$. 


\section{Conclusions}

In summary, it has been demonstrated, that at low $\left(0.01-0.1 \mathrm{mg} \cdot \mathrm{L}^{-1}\right)$ and moderate concentration $\left(1.0-10 \mathrm{mg} \cdot \mathrm{L}^{-1}\right)$ of nitrite ions in anolyte-model wastewater, the voltage drop in MFC linearly depends on the logarithm of concentration of nitrite ions proving the potential of the use of MFC-based biosensor for the quantitative monitoring of nitrite ion concentrations in wastewater and other surface water. However, higher concentrations $\left(100-1000 \mathrm{mg} \cdot \mathrm{L}^{-1}\right)$ of nitrite ions in anolyte-model wastewater could not be accurately quantified due to a significant drop in MFC voltage. In this case MFC can potentially serve as a bioelectrochemical early warning device for extremely high nitrite pollution. MFCbased biosensor offers a sustainable low-cost real-time in situ alternative to the monitoring by periodic sampling for laboratory testing.

Author Contributions: Conceptualization, E.G.; methodology, E.G.; formal analysis, A.K., K.K., N.Ž., E.G.; investigation, A.K., K.K., N.Ž., I.J., E.G.; writing—original draft preparation, K.K., E.G.; writing—review and editing, K.K., I.J., E.G.; visualization, N.Ž., E.G.; funding acquisition, E.G. All authors have read and agreed to the published version of the manuscript.

Funding: Part of the research leading to these results has received a funding from European Social Fund (project No 09.3.3.-LMT-K-712-22-0044) under grant agreement with the Research Council of Lithuania (LMTLT).

Institutional Review Board Statement: Not applicable.

Informed Consent Statement: Not applicable.

Data Availability Statement: All datasets generated for this study are included in the article.

Conflicts of Interest: The authors declare no conflict of interest. The funders had no role in the design of the study; in the collection, analyses, or interpretation of data; in the writing of the manuscript, or in the decision to publish the results.

\section{References}

1. Munoz-Cupa, C.; Hu, Y.; Xu, C.; Bassi, A. An overview of microbial fuel cell usage in wastewater treatment, resource recovery and energy production. Sci. Total Environ. 2021, 754, 142429. [CrossRef] [PubMed]

2. Zhou, T.; Han, H.; Liu, P.; Xiong, J.; Tian, F.; Li, X. Microbial Fuels Cell-Based Biosensor for Toxicity Detection: A Review. Sensors 2017, 17, 2230. [CrossRef]

3. Du, Z.; Li, H.; Gu, T. A state of the art review on microbial fuel cells: A promising technology for wastewater treatment and bioenergy. Biotechnol. Adv. 2007, 25, 464-482. [CrossRef]

4. Logan, B.E.; Hamelers, H.; Rozendal, R.; Schröder, U.; Keller, J.; Freguia, S.; Aelterman, P.; Verstraete, W.; Rabaey, K. Microbial Fuel Cells: Methodology and Technologyt. Environ. Sci. Technol. 2006, 40, 5181-5192. [CrossRef]

5. Trapero, J.; Horcajada, L.; Linares, J.J.; Lobato, J. Is microbial fuel cell technology ready? An economic answer towards industrial commercialization. Appl. Energy 2017, 185, 698-707. [CrossRef]

6. Ardakani, M.N.; Gholikandi, G.B. Microbial fuel cells (MFCs) in integration with anaerobic treatment processes (AnTPs) and membrane bioreactors (MBRs) for simultaneous efficient wastewater/sludge treatment and energy recovery-A state-of-the-art review. Biomass Bioenergy 2020, 141, 105726. [CrossRef]

7. Rabaey, K.; Verstraete, W. Microbial fuel cells: Novel biotechnology for energy generation. Trends Biotechnol. 2005, 23, 291-298. [CrossRef]

8. Santoro, C.; Arbizzani, C.; Erable, B.; Ieropoulos, I. Microbial fuel cells: From fundamentals to applications. A review. J. Power Sources 2017, 356, 225-244. [CrossRef]

9. Serra, P.; Espirito-Santo, A. Sourcing power with microbial fuel cells: A timeline. J. Power Sources 2021, 482, 228921. [CrossRef]

10. Liang, P.; Duan, R.; Jiang, Y.; Zhang, X.; Qiu, Y.; Huang, X. One-year operation of 1000-L modularized microbial fuel cell for municipal wastewater treatment. Water Res. 2018, 141, 1-8. [CrossRef]

11. Yu, J.; Park, Y.; Widyaningsih, E.; Kim, S.; Kim, Y.; Lee, T. Microbial fuel cells: Devices for real wastewater treatment, rather than electricity production. Sci. Total Environ. 2021, 775, 145904. [CrossRef]

12. Logan, B.E.; Rabaey, K. Conversion of Wastes into Bioelectricity and Chemicals by Using Microbial Electrochemical Technologies. Science 2012, 337, 686-690. [CrossRef]

13. Jadhav, D.; Ray, S.G.; Ghangrekar, M.M. Third generation in bio-electrochemical system research-A systematic review on mechanisms for recovery of valuable by-products from wastewater. Renew. Sustain. Energy Rev. 2017, 76, 1022-1031. [CrossRef]

14. De Vrieze, J.; Arends, J.B.; Verbeeck, K.; Gildemyn, S.; Rabaey, K. Interfacing anaerobic digestion with (bio)electrochemical systems: Potentials and challenges. Water Res. 2018, 146, 244-255. [CrossRef] 
15. Naik, S.; Jujjavarappu, S.E. Self-powered and reusable microbial fuel cell biosensor for toxicity detection in heavy metal polluted water. J. Environ. Chem. Eng. 2021, 9, 105318. [CrossRef]

16. Kaur, A.; Kim, J.R.; Michie, I.; Dinsdale, R.; Guwy, A.J.; Premier, G. Microbial fuel cell type biosensor for specific volatile fatty acids using acclimated bacterial communities. Biosens. Bioelectron. 2013, 47, 50-55. [CrossRef]

17. Huang, S.; Shen, M.; Ren, Z.J.; Wu, H.; Yang, H.; Si, B.; Lin, J.; Liu, Z. Long-term in situ bioelectrochemical monitoring of biohythane process: Metabolic interactions and microbial evolution. Bioresour. Technol. 2021, 332, 125119. [CrossRef] [PubMed]

18. Sun, J.-Z.; Kingori, G.P.; Si, R.-W.; Zhai, D.-D.; Liao, Z.-H.; Sun, D.-Z.; Zheng, T.; Yong, Y.-C. Microbial fuel cell-based biosensors for environmental monitoring: A review. Water Sci. Technol. 2015, 71, 801-809. [CrossRef]

19. Yang, H.; Zhou, M.; Liu, M.; Yang, W.; Gu, T. Microbial fuel cells for biosensor applications. Biotechnol. Lett. 2015, 37, 2357-2364. [CrossRef] [PubMed]

20. Cui, Y.; Lai, B.; Tang, X. Microbial Fuel Cell-Based Biosensors. Biosensors 2019, 9, 92. [CrossRef]

21. Hao, S.; Sun, X.; Zhang, H.; Zhai, J.; Dong, S. Recent development of biofuel cell based self-powered biosensors. J. Mater. Chem. B 2020, 8, 3393-3407. [CrossRef]

22. Sonawane, J.; Ezugwu, C.I.; Ghosh, P.C. Microbial Fuel Cell-Based Biological Oxygen Demand Sensors for Monitoring Wastewater: State-of-the-Art and Practical Applications. ACS Sens. 2020, 5. [CrossRef] [PubMed]

23. Philips, S.; Laanbroek, H.J.; Verstraete, W. Origin, causes and effects of increased nitrite concentrations in aquatic environments. Rev. Environ. Sci. Bio/Technol. 2002, 1, 115-141. [CrossRef]

24. Iijima, S. Helical microtubules of graphitic carbon. Nat. Cell Biol. 1991, 354, 56-58. [CrossRef]

25. Guidelines for Drinking-Water Quality, 4th ed.; World Health Organization: Geneva, Switzerland, 2017; Available online: https: / / apps.who.int/iris/bitstream/handle/10665/254637/9789241549950-eng.pdf (accessed on 10 August 2019).

26. Schullehner, J.; Stayner, L.; Hansen, B. Nitrate, Nitrite, and Ammonium Variability in Drinking Water Distribution Systems. Int. J. Environ. Res. Public Health 2017, 14, 276. [CrossRef] [PubMed]

27. Nitrate/Nitrite Fact Sheet. Available online: www.Wqa.Org/Portals/0/Technical/Technical\%20Fact $\% 20$ Sheets $/ 2014$ _NitrateNitrite.Pdf (accessed on 27 June 2021).

28. Shankar, K.; Mehendale, H.M. Oxidative Stress. In Encyclopedia of Toxicology; Elsevier: Amsterdam, The Netherlands, 2014; pp. 735-737. ISBN 978-0-12-386455-0.

29. Peng, Y.; Zhu, G. Biological nitrogen removal with nitrification and denitrification via nitrite pathway. Appl. Microbiol. Biotechnol. 2006, 73, 15-26. [CrossRef] [PubMed]

30. International Organization for Standardization. ISO 6777:1984 Water Quality—Determination of Nitrite-Molecular Absorption Spectrometric Method. 1984. Available online: https:/ / www.iso.org/standard/13273.html (accessed on 1 September 2020).

31. Jiang, J.; Fan, W.; Du, X. Nitrite electrochemical biosensing based on coupled graphene and gold nanoparticles. Biosens. Bioelectron. 2014, 51, 343-348. [CrossRef] [PubMed]

32. Gholivand, M.-B.; Jalalvand, A.R.; Goicoechea, H.C. Computer-assisted electrochemical fabrication of a highly selective and sensitive amperometric nitrite sensor based on surface decoration of electrochemically reduced graphene oxide nanosheets with CoNi bimetallic alloy nanoparticles. Mater. Sci. Eng. C 2014, 40, 109-120. [CrossRef] [PubMed]

33. Radhakrishnan, S.; Krishnamoorthy, K.; Sekar, C.; Wilson, J.; Kim, S.-J. A highly sensitive electrochemical sensor for nitrite detection based on $\mathrm{Fe}_{2} \mathrm{O}_{3}$ nanoparticles decorated reduced graphene oxide nanosheets. Appl. Catal. B Environ. 2014, 148-149, 22-28. [CrossRef]

34. Luo, X.; Pan, J.; Pan, K.; Yu, Y.; Zhong, A.; Wei, S.; Li, J.; Shi, J.; Li, X. An electrochemical sensor for hydrazine and nitrite based on graphene-cobalt hexacyanoferrate nanocomposite: Toward environment and food detection. J. Electroanal. Chem. 2015, 745, 80-87. [CrossRef]

35. Huang, S.-S.; Liu, L.; Mei, L.-P.; Zhou, J.-Y.; Guo, F.-Y.; Wang, A.-J.; Feng, J.-J. Electrochemical sensor for nitrite using a glassy carbon electrode modified with gold-copper nanochain networks. Microchim. Acta 2015, 183, 791-797. [CrossRef]

36. Zhang, S.; Li, B.; Sheng, Q.; Zheng, J. Electrochemical sensor for sensitive determination of nitrite based on the CuS-MWCNT nanocomposites. J. Electroanal. Chem. 2016, 769, 118-123. [CrossRef]

37. Palanisamy, S.; Thirumalraj, B.; Chen, S.-M. A novel amperometric nitrite sensor based on screen printed carbon electrode modified with graphite/ $\beta$-cyclodextrin composite. J. Electroanal. Chem. 2016, 760, 97-104. [CrossRef]

38. Mao, Y.; Bao, Y.; Han, D.-X.; Zhao, B. Research Progress on Nitrite Electrochemical Sensor. Chin. J. Anal. Chem. 2018, 46, 147-155. [CrossRef]

39. Li, X.; Ping, J.; Ying, Y. Recent developments in carbon nanomaterial-enabled electrochemical sensors for nitrite detection. TrAC Trends Anal. Chem. 2019, 113, 1-12. [CrossRef]

40. Sun, C.; Pan, W.; Zheng, D.; Zheng, Y.; Zhu, J. An electrochemical sensor for nitrite using a glassy carbon electrode modified with $\mathrm{Cu} / \mathrm{CBSA}$ nanoflower networks. Anal. Methods 2019, 11, 4998-5006. [CrossRef]

41. Sharma, M.; Bajracharya, S.; Gildemyn, S.; Patil, S.A.; Alvarez-Gallego, Y.; Pant, D.; Rabaey, K.; Dominguez-Benetton, X. A critical revisit of the key parameters used to describe microbial electrochemical systems. Electrochim. Acta 2014, 140, 191-208. [CrossRef]

42. Lu, H.; Oehmen, A.; Virdis, B.; Keller, J.; Yuan, Z. Obtaining highly enriched cultures of Candidatus Accumulibacter phosphates through alternating carbon sources. Water Res. 2006, 40, 3838-3848. [CrossRef]

43. Sotres, A.; Tey, L.; Bonmatí, A.; Viñas, M. Microbial community dynamics in continuous microbial fuel cells fed with synthetic wastewater and pig slurry. Bioelectrochemistry 2016, 111, 70-82. [CrossRef] 
44. Griškonis, E.; Ilginis, A.; Jonuškienè, I.; Raslavičius, L.; Jonynas, R.; Kantminienè, K. Enhanced Performance of Microbial Fuel Cells with Anodes from Ethylenediamine and Phenylenediamine Modified Graphite Felt. Processes 2020, 8, 939. [CrossRef]

45. Yang, Q.; Keerthisinghe, T.P.; Tan, T.R.J.; Cao, X.; Setyawati, M.I.; DeLoid, G.; Ng, K.W.; Loo, S.C.J.; Demokritou, P.; Fang, M. A high-throughput method to characterize the gut bacteria growth upon engineered nanomaterial treatment. Environ. Sci. Nano 2020, 7, 3155-3166. [CrossRef] [PubMed]

46. Huang, J.-S.; Yang, P.; Li, C.-M.; Guo, Y.; Lai, B.; Wang, Y.; Feng, L.; Zhang, Y. Effect of Nitrite and Nitrate Concentrations on the Performance of AFB-MFC Enriched with High-Strength Synthetic Wastewater. Biotechnol. Res. Int. 2015, 2015, 1-6. [CrossRef] [PubMed]

47. Torres, C.I.; Marcus, A.K.; Parameswaran, P.; Rittmann, B.E. Kinetic Experiments for Evaluating the Nernst-Monod Model for Anode-Respiring Bacteria (ARB) in a Biofilm Anode. Environ. Sci. Technol. 2008, 42, 6593-6597. [CrossRef] [PubMed]

48. Ucar, D.; Zhang, Y.; Angelidaki, I. An Overview of Electron Acceptors in Microbial Fuel Cells. Front. Microbiol. $2017,8,643$. [CrossRef] 